\title{
Progesterone-induced secretion of a retinol-binding protein in the pig uterus
}

\author{
K. L. Adams, F. W. Bazer and R. M. Roberts \\ Department of Animal Science and Department of Biochemistry and Molecular Biology, \\ University of Florida, Gainesville, Florida 32603, U.S.A.
}

\begin{abstract}
Summary. A retinol binding protein(s) of molecular weight about 17000 has been demonstrated in uterine secretions from pigs in the luteal phase of the oestrous cycle. This protein was induced in ovariectomized sows treated with progesterone or progesterone plus oestradiol, but not in sows given oestradiol or corn oil. The vitamin A content of secretions from progesterone-treated animals also increased relative to those in controls. The apparent $K_{\mathrm{d}}$ of the binding protein for retinol was $2.6 \times 10^{-6} \mathrm{M}$. The protein had some affinity for retinoic acid and oleic acid, but did not bind retinyl esters or retinal. The protein probably comprises $5 \%$ or less of the total fraction of low molecular weight proteins induced by progesterone. A similar protein was found in allantoic fluid of pregnant animals, suggesting that, like uteroferrin, it serves to transport a water-insoluble nutrient from the maternal uterine endometrium to the conceptus.
\end{abstract}

\section{Introduction}

Major involvement of uterine secretory activity in the development of the conceptus is most likely in animals in which placentation is of the epitheliochorial or diffuse type (Steven, 1975). In the pig, for example, there is no erosion of the uterine epithelium by the trophoblast and secretions probably play an important role throughout pregnancy, and not just during the period of attachment and implantation. Murray, Bazer, Wallace \& Warnick (1972) investigated the pattern of uterine secretions throughout the oestrous cycle of pigs by Sephadex G-200 chromatography and identified 5 size fractions of protein. The 3 fractions of highest molecular weight (I-III) were present on all days of the cycle, but Fractions IV and V appeared only during the luteal phase. These same fractions can be induced in ovariectomized pigs by daily injections of progesterone (Knight, Bazer \& Wallace, 1973). Fraction IV consists largely of a purple, iron-containing glycoprotein called uteroferrin (Roberts \& Bazer, 1980). This protein is secreted by the glandular and surface epithelium of uterine endometrium, crosses the chorioallantois at specialized regions called areolae (Chen, Bazer, Gebhart \& Roberts, 1975) and at least part of it accumulates temporarily in the allantoic fluid (Bazer et al., 1975) where the iron is released (Buhi, Bazer, Ducsay, Chun \& Roberts, 1979). The discovery of uteroferrin suggested that additional carrier proteins might exist which serve to transport other nutrient molecules to the conceptus. Several reports have shown that retinol- and retinoic acid-binding proteins exist in serum (Goodman, 1974) and in various tissues, including the endometrium, of a number of mammalian species (Ong \& Chytil, 1975; Chytil, Page \& Ong, 1975). Retinol is also an essential nutrient for the maintenance of reproductive function and fetal development (Thompson, Howell \& Pitt, 1964). It seemed likely, therefore, that carrier molecules might exist to transport this water-insoluble vitamin from the maternal uterine endometrium to the conceptus and this possibility was investigated in the present study. 


\section{Materials and Methods}

Radiochemicals. Tritiated all-trans-retinol (sp. act. $2.66 \mathrm{Ci} / \mathrm{mmol}$ ) was purchased from New England Nuclear Corp (Boston, Massachusetts). A stock solution was prepared in ethanol containing $20 \mu \mathrm{Ci}\left[{ }^{3} \mathrm{H}\right] \mathrm{retinol}$ and $1 \mathrm{mg} \alpha$-tocopherol $/ \mathrm{ml}$. This was stored in foil-wrapped vials at $3^{\circ} \mathrm{C}$ under $\mathrm{N}_{2}$.

Other reagents. Crystalline all-trans-retinol and retinoic acid, were obtained from Sigma (St Louis, Missouri) and dissolved at a concentration of $1 \mathrm{mg} / \mathrm{ml}$ in absolute ethanol in the presence of $\alpha$-tocopherol $(1 \mathrm{mg} / \mathrm{ml})$. They were stored at $3^{\circ} \mathrm{C}$ in darkness under $\mathrm{N}_{2}$. Samples were withdrawn through a septum closure by means of a syringe. The competing lipids, retinoic acid, oleic acid, retinyl acetate, retinyl palmitate and retinal, were also obtained from Sigma and stored in a similar manner.

Uterine secretions. Luteal-phase secretions were flushed from the uteri of intact gilts on Day 15 of the oestrous cycle by methods described in detail elsewhere (Bazer, Sharp \& Roberts, 1978). Hormone replacement therapy involved 12 gilts that were ovariectomized on Day 4 of the oestrous cycle and treated daily for 11 days with $4 \mathrm{ml}$ corn oil (Group 1); $100 \mu \mathrm{g}$ oestradiol valerate (Group 2); $200 \mathrm{mg}$ progesterone (Group 3), or $200 \mathrm{mg}$ progesterone $+100 \mu \mathrm{g}$ oestradiol valerate (Group 4). Corn oil was used as the vehicle for all the steroids and corn-oil-treated animals constituted the control group. Injections were given subcutaneously. Another group of 3 animals were injected with progesterone $(200 \mathrm{mg} / \mathrm{day})$ for 60 days in order to obtain large quantities of uterine secretions. All flushings were centrifuged $(10000 \mathrm{~g})$ to remove large particles, filtered through a $0.45 \mu \mathrm{m}$ filter and stored frozen.

Preparation of Fraction $V$. Uterine flushings (100-500 mg protein) were dialysed for $24 \mathrm{~h}$

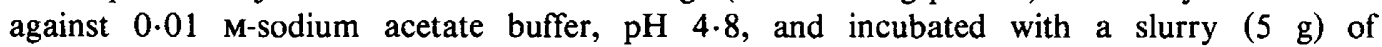
carboxymethyl cellulose which binds uteroferrin and other basic proteins (Schlosnagle, Bazer, Tsibris \& Roberts, 1976). The mixture was filtered on a Buchner funnel under reduced pressure and portions of the filtrate (usually about $75 \%$ of the total protein) fractionated on a column of BioGel P-100 (Bazer et al., 1975) or Sephadex G-200 (Murray et al., 1972) in presence of 0.01 $\mathrm{M}$-acetate buffer and $0.33 \mathrm{M}-\mathrm{NaCl}$. All proteins which eluted in the approximate molecular weight range of the protein standards myoglobin (mol. wt 17000 ) and chymotrypsinogen (mol. wt 25000 ) were collected. A typical elution pattern from BioGel P-100 is shown in Text-fig. 1. The Fraction $\mathrm{V}$ proteins were pooled and frozen at $-20^{\circ} \mathrm{C}$ until use.

Allantoic fluid and serum. Allantoic fluid was collected from animals on Days 30, 45, 60, 75, 90 and 105 of gestation as described by Bazer et al. (1975). The fluid was centrifuged and filtered as described for uterine secretions. Blood was withdrawn from the radial vein at surgery, allowed to clot, centrifuged at $500 \mathrm{~g}$ and the serum was decanted. Serum from animals at Day 3 of the oestrous cycle and Day 45 of pregnancy was evaluated for the presence of retinol-binding protein.

Assay for retinol-binding protein $(R B P)$. In the standard assay for $\mathrm{RBP}$, the incubation mixture contained $44 \mu \mathrm{g}$ Fraction $\mathrm{V}$ protein in $800 \mu$ l buffer $(0.01 \mathrm{M}$-phosphate, $\mathrm{pH} 7 \cdot 1 ; 0.1$ $\mathrm{M}-\mathrm{NaCl})$ and $76 \mathrm{pmol}\left[{ }^{3} \mathrm{H}\right]$ retinol $(10 \mu \mathrm{l}$ stock solution; $0.2 \mu \mathrm{Ci})$ plus various amounts of unlabelled retinol in a final volume of $1.0 \mathrm{ml}$. The incubation was carried out in darkness under an atmosphere of $\mathrm{N}_{2}$ at $3^{\circ} \mathrm{C}$. A few crystals of sucrose $(50-100 \mathrm{mg}$ ) were then added (to increase sample density). The free and bound $\left[{ }^{3} \mathrm{H}\right]$ retinol were separated by chromatography at room temperature on columns of BioGel-P-30 $(1 \times 23 \mathrm{~cm})$ equilibrated with $0.01 \mathrm{M}$-phosphate buffer $(\mathrm{pH} 7 \cdot 1)$ in the presence of $0.1 \mathrm{M}-\mathrm{NaCl}$. Fractions $(2 \mathrm{ml})$ were collected and $0.2 \mathrm{ml}$ aliquots from each were counted for ${ }^{3} \mathrm{H}$ with a Beckman LS-230 liquid scintillation counter. All binding assays were carried out in duplicate. Total ${ }^{3} \mathrm{H}$ associated with Fraction $\mathrm{V}$ was determined. The ratio between bound and free retinol was then plotted against the total amount of retinol bound for each of the concentrations of retinol used in the experiment (Scatchard, 1949). Values were corrected for non-specific binding by measuring bound/free values from assays carried out at three saturating concentrations of retinol. 
Because free $\left[{ }^{3} \mathrm{H}\right.$ lretinol binds to the column, the BioGel P-30, or to plastic tubing, and elutes only gradually with aqueous buffers, the columns were washed with two column volumes of buffer containing $0.2 \%(\mathrm{v} / \mathrm{v})$ Triton $\mathrm{X}-100$ between runs. This procedure eluted the adsorbed retinol.

Assay for RBP in serum, allantoic fluid and uterine secretions. Incubations were carried out essentially as those described above for Fraction $\mathrm{V}$ protein in $1 \mathrm{ml}$ of $0.01 \mathrm{M}$-phosphate buffer $\mathrm{pH} 7.1$ containing $0.1 \mathrm{M}-\mathrm{NaCl} .\left[{ }^{3} \mathrm{H}\right]$ Retinol $(0.2 \mu \mathrm{Ci})$ was used to measure binding at a concentration of $76 \mathrm{pmol} / \mathrm{ml}$. Serum and allantoic fluid (Day 60) were assayed for the presence of RBP at protein concentrations of 2.5 and $2.06 \mathrm{mg} / \mathrm{ml}$ respectively. Crude uterine flushings from the different treatment groups were assayed at a protein concentration of $1 \mathrm{mg} / \mathrm{ml}$, those from animals at Day 15 of the oestrous cycle at $1.2 \mathrm{mg} / \mathrm{ml}$. These materials were incubated for $2 \mathrm{~h}$ at $3^{\circ} \mathrm{C}$, and chromatography carried out on columns of Bio-gel P-100 $(2 \times 36 \mathrm{~cm})$ or Sephadex G-75 $(2 \times 50 \mathrm{~cm})$ to separate $\left[{ }^{3} \mathrm{H}\right]$-retinol bound to proteins from the free vitamin.

Molecular weight determination. The molecular weight of the RBP was measured by gel filtration on a column $(2 \times 50 \mathrm{~cm})$ of Sephadex G-75 which had been calibrated with ovalbumin, a-chymotrypsin, horse myoglobin and ribonuclease $\mathrm{A}$.

$D E A E$-cellulose ion-exchange chromatography. Fraction $\mathrm{V}$ protein $(3.2 \mathrm{mg} / \mathrm{ml})$ was dialysed for $24 \mathrm{~h}$ against 4 litres of $0.01 \mathrm{M}$-Tris- $\mathrm{HCl}, \mathrm{pH} 8 \cdot 2$, and then incubated with $390 \mathrm{pmol}$ $\left[{ }^{3} \mathrm{H}\right.$ ]retinol $(1 \mu \mathrm{Ci})$ for $2 \mathrm{~h}$. At the end of the incubation, the protein solution was applied to a DEAE-cellulose column $(11 \times 1 \mathrm{~cm})$. After washing the column with $50 \mathrm{ml} 0.01 \mathrm{M}-\mathrm{Tris}-\mathrm{HCl}$, $\mathrm{pH} 8 \cdot 2$, the bound proteins were eluted with a linear gradient $(250 \mathrm{ml})$ of $\mathrm{NaCl}(0-0.3 \mathrm{M})$ and the fractions were assayed for absorbance at $280 \mathrm{~nm}$ and radioactivity.

Determination of vitamin $A$. The vitamin A content of uterine flushings and allantoic fluid was determined by a modification of the method of Selvanaja \& Susheela (1970). A $0.2 \mathrm{ml}$ sample of each flushing was mixed with $1 \mathrm{M}$-ethanolic $\mathrm{KOH}(1 \mathrm{ml})$ and heated to extract the lipid. Xylene $(4.0 \mathrm{ml})$ was added and the solution was centrifuged for $10 \mathrm{~min}$ at $800 \mathrm{~g}$. The organic phase was withdrawn and assayed for relative fluorescence in an Amico-Bowman fluorometer ( $350 \mathrm{~nm}$ excitation; $490 \mathrm{~nm}$ emission) and compared to that for a standard curve of all trans-retinol in xylene.

Statistical analysis. Analysis of variance (Steel \& Torrie, 1960) was used to determine whether RBP content or vitamin A levels in uterine flushings were affected by treatment.

Determination of protein. Protein content of solutions was measured by the method of Lowry, Rosebrough, Farr \& Randall (1951), using bovine serum albumin as a standard. Protein in column eluates was monitored by its absorption at $280 \mathrm{~nm}$.

\section{Results}

\section{Binding of $\left[{ }^{3} \mathrm{H}\right]$ retinol to secreted uterine proteins}

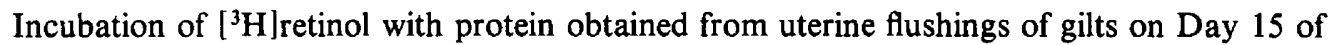
the oestrous cycle for $4 \mathrm{~h}$ followed by chromatography on Biogel P-100 revealed 3 major protein peaks (Text-fig. 1). Radioactivity was associated only with protein(s) eluting with the void volume and the last fraction containing proteins with the lowest molecular weights. These low molecular weight proteins corresponded with Fraction V proteins as determined by Sephadex G-200 chromatography (Murray et al., 1972), while proteins in the void volume contained Sephadex G-200 Fractions I, II and III. The radioactivity eluting between fractions 40 and 50 was not free retinol, but a small amount of a tritiated impurity in the commercial preparation of $\left[{ }^{3} \mathrm{H}\right]$ retinol, which did not partition into organic solvents and was volatile. Free $\left[{ }^{3} \mathrm{H}\right]$ retinol did not appear in the elution profile and presumably became bound to the column material.

When such an incubation was carried out after addition of $5 \mu \mathrm{mol}$ unlabelled retinol, the radioactivity associated with Fraction $\mathrm{V}$ was reduced by over $80 \%$ with little effect on the void volume peak. It was therefore assumed that the Fraction $V$ protein peak contained a relatively 


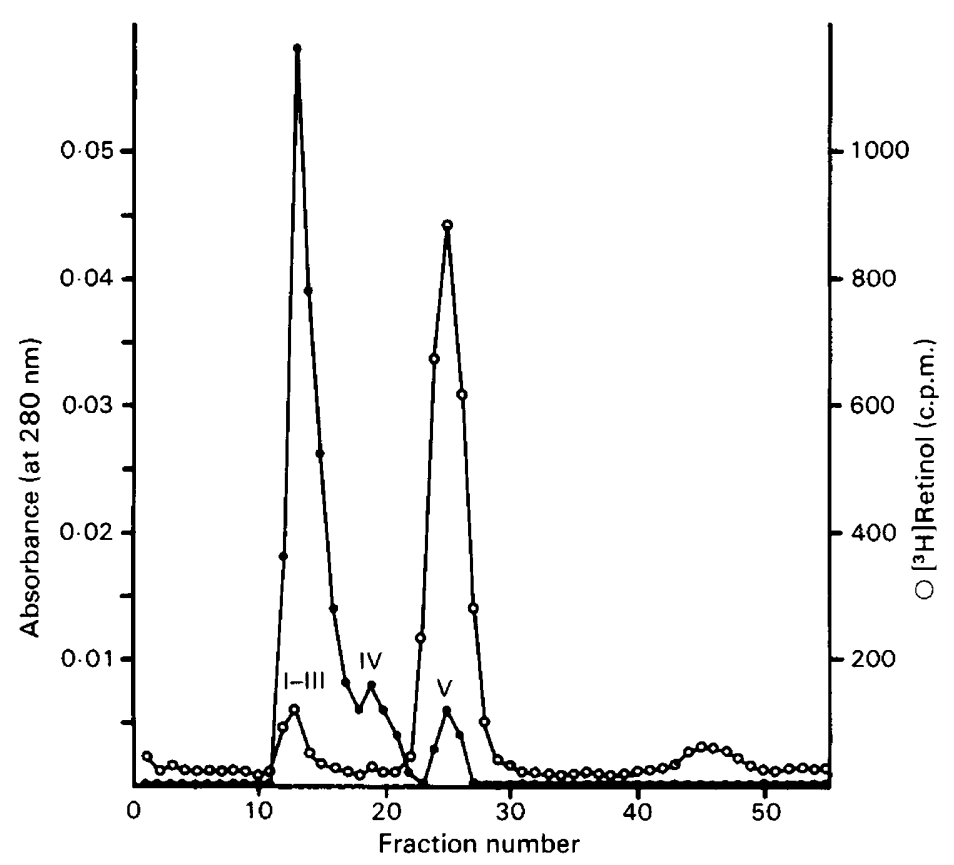

Text-fig. 1. Biogel P-100 gel chromatography of crude porcine uterine secretions after incubation with $\left[{ }^{3} \mathrm{H}\right]$ retinol. Uterine proteins $(1.2 \mathrm{mg})$ from gilts at Day 15 of the oestrous cycle were incubated with $0.01 \mu \mathrm{Ci}\left[{ }^{3} \mathrm{H}\right]$ retinol for $4 \mathrm{~h}$ before chromatography. Column size was $2 \times$ $46 \mathrm{~cm}$ and $2-\mathrm{ml}$ fractions were collected. Eluant buffer was $0.3 \mathrm{M}-\mathrm{NaCl}$ in $0.02 \mathrm{M}$-phosphate, $\mathrm{pH}$ 7.1. Radioactivity (O) in $0.2 \mathrm{ml}$ samples and absorbance at $280 \mathrm{~nm}$ (O) were followed throughout the elution. The void volume of the column was around Fraction 13 and the included volume (position at which glucose elutes) was around Fraction 35. Roman numerals (I-V) indicate protein fractions as designated by Murray et al. (1972).

specific, low-capacity binding protein, whereas the binding associated with the void volume material was considered non-specific binding.

\section{Molecular weight of $R B P$}

A sample of Fraction $\mathrm{V}$ protein $(100 \mu \mathrm{g})$ purified from Day-15 uterine flushings was incubated with $\left[{ }^{3} \mathrm{H}\right]$ retinol $(0.2 \mu \mathrm{Ci})$ under standard conditions and chromatographed on the calibrated Sephadex G-75 column. The radioactivity appeared as a symmetrical peak close to the elution position of myoglobin and slightly behind most of the Fraction $\mathrm{V}$ protein. The estimated molecular weight of RBP was $17000 \pm 3000$, and the estimated molecular weight of all Fraction V proteins was $20000 \pm 3000$.

\section{Binding constant for retinol}

In initial experiments using $76 \mathrm{pmol}$ retinol $(0.2 \mu \mathrm{Ci})$ binding was complete within $1 \mathrm{~h}$ and linearly dependent upon protein concentrations. In a further series of experiments using a fixed concentration of Fraction $\mathrm{V}$ protein $(44 \mu \mathrm{g} / \mathrm{ml})$ the relation between retinol concentration in the incubation medium and the amount of retinol binding to protein was investigated (Text-fig. 2). The amount of non-specific binding was determined by averaging the bound/free values from the points at which saturating amounts of unlabelled retinol were present (i.e. 15000,20000 and $30000 \mathrm{pmol}$ ). The amount of specific binding was then calculated for each concentration of 
retinol. When the results were plotted according to the method of Scatchard (1949), a $K_{d}$ of 2.6 $\times 10^{-6} \mathrm{M}$ was calculated for the binding of retinol to total Fraction $\mathrm{V}$ protein. Assuming an average molecular weight of 20000 for the proteins in Fraction V, approximately $6 \times 10^{-2} \mathrm{~mol}$ retinol were bound per mol protein.

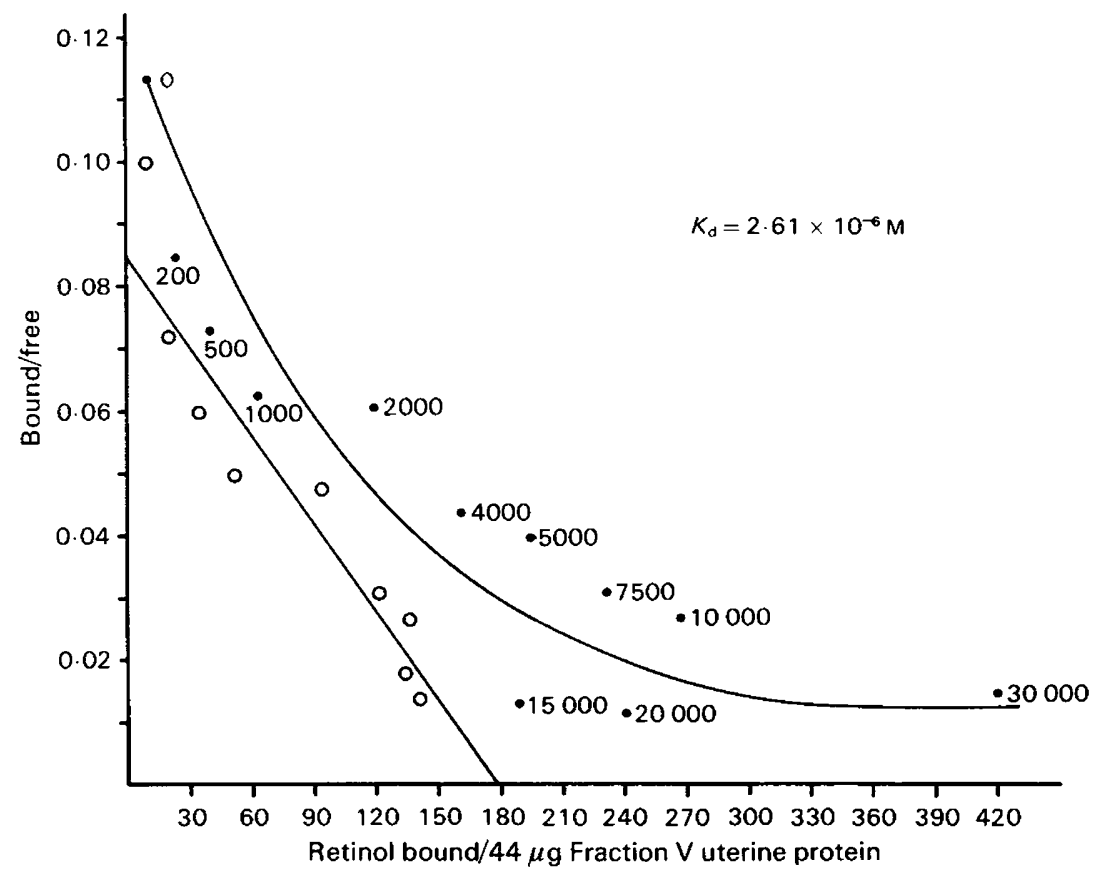

Text-fig. 2. Scatchard plot of equilibrium binding data for retinol to Fraction $V$ porcine uterine protein. Amount of retinol bound (B) was determined by Biogel P-30 column chromatography after incubating increasing amounts of retinol with a fixed $(44 \mu \mathrm{g})$ amount of protein. Experimental values are shown by closed circles (0). The amount of retinol added (in pmol) is shown next to each point. Open circles $(O)$ show corrected values plotted by linear regression after subtracting for non-specific binding.

\section{Ion-exchange chromatography of retinol binding protein}

$\left[{ }^{3} \mathrm{H}\right]$ Retinol $(1 \mu \mathrm{Ci})$ was incubated with Fraction $\mathrm{V}$ protein in $2 \mathrm{ml}$ buffer under the standard assay condition. After $2 \mathrm{~h}$ the protein was analysed by ion-exchange chromatography on DEAE-cellulose (Text-fig. 3). Two peaks of radioactivity were detected which eluted at about $0.17 \mathrm{M}-$ and $0.2 \mathrm{M}-\mathrm{NaCl}$, respectively. They appeared considerably later in the elution profile than the bulk of the Fraction V proteins. Each appeared at the leading edge of two minor protein peaks. These results indicated that RBPs comprise only a minor fraction of total Fraction V protein.

\section{Specificity of binding}

The effect of a 197-fold molar excess of competing ligand on the binding of retinol ( $76 \mathrm{pmol}$ ) to Fraction $V$ protein $(44 \mu \mathrm{g})$ was tested under the standard conditions for incubation and analysis. Unlabelled retinol displaced $78.5 \%$ of $\left[{ }^{3} \mathrm{H}\right]$ retinol from RBP, but retinal and the retiny] derivatives had little effect (Table 1). Some competition was observed with retinoic and oleic acids. 
$K . L$. Adams et al.

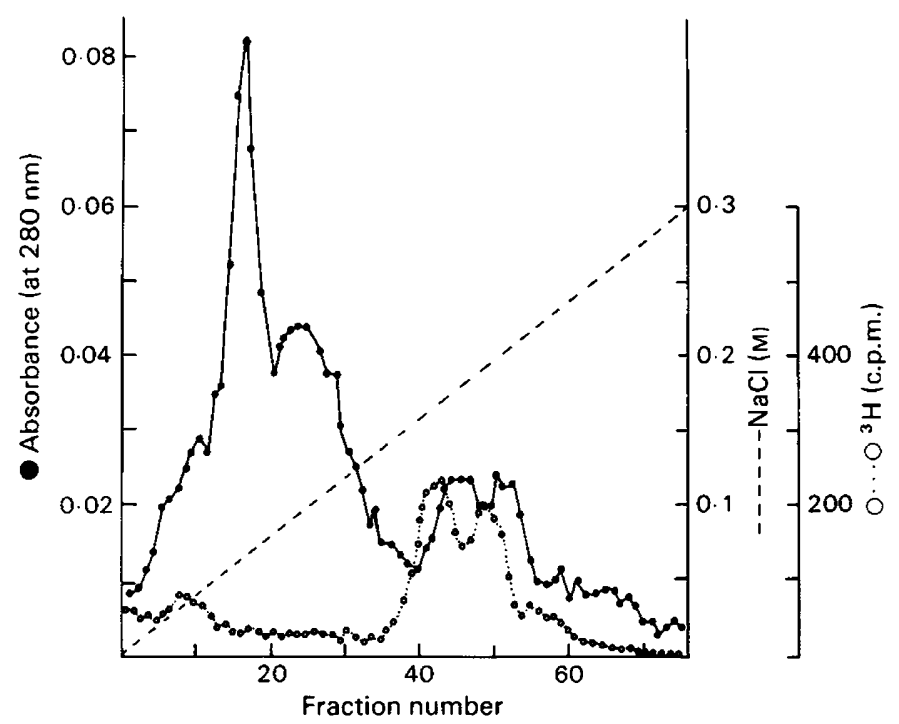

Text-fig. 3. DEAE ion-exchange chromatography of Fraction $V$ proteins after incubation in the presence of $\left[{ }^{3} \mathrm{H}\right]$ retinol. Column size was $11 \times 1 \mathrm{~cm}$ and proteins were eluted with a linear gradient $(250 \mathrm{ml} ; 0.01-0.3 \mathrm{M}-\mathrm{NaCl})$. Each fraction $(3.0 \mathrm{ml})$ was analysed for protein and radioactivity.

Table 1. Competition between various retinol analogues and $\left[{ }^{3} \mathrm{H}\right]$ retinol for binding to Fraction $\mathrm{V}$ protein from uterine flushings of gilts

\begin{tabular}{lcc}
\hline \multicolumn{1}{c}{ Ligand* } & $\begin{array}{c}\text { No. of } \\
\text { determinations }\end{array}$ & $\begin{array}{c}{\left[{ }^{3} \mathrm{H}\right] \text { Retinol binding }} \\
\text { (\% competition of } \\
\text { ligand) } \dagger\end{array}$ \\
\hline Retinol (control) & 2 & $100 \cdot 0$ \\
Retinoic acid & 4 & $34 \cdot 1$ \\
Oleic acid & 4 & $29 \cdot 3$ \\
Retinyl acetate & 2 & 0 \\
Retinyl palmitate & 2 & 0 \\
Retinal & 2 & 0 \\
\hline
\end{tabular}

* Competition between $\left[{ }^{3} \mathrm{H} / \mathrm{retinol}(76 \mathrm{pmol} / \mathrm{ml})\right.$ and each competing ligand at 197 -fold greater concentration (15000 $\mathrm{pmol} / \mathrm{ml})$.

† Competition between $\left[{ }^{3} \mathrm{H}\right]$ retinol and $15000 \mathrm{pmol}$ unlabelled retinol resulted in a $21.5 \%$ displacement which has been taken into account when calculating competition for the other ligands.

\section{Hormonal control of $R B P$}

The uterine secretions from the gilts in Groups 1-4 were collected and assayed for their ability to bind $\left[{ }^{3} \mathrm{H} / \mathrm{retinol}(76 \mathrm{pmol} / \mathrm{ml})\right.$. Total $\left[{ }^{3} \mathrm{H}\right] \mathrm{retinol}$ binding to total Fraction $\mathrm{V}$ recovered per uterine horn for each of the various hormonal treatments was calculated (Table 2). Because these binding assays were carried out under non-saturating conditions of retinol they do not represent the total retinol binding capacity of the flushings. Under saturating conditions (10 000 pmol retinol in $1 \mathrm{ml}$ buffer) binding would be approximately 20 -fold greater. Only small quantities of RBP were detected in the flushings from gilts receiving corn oil and oestradiol, but significantly greater amounts were present in flushings from gilts receiving progesterone alone or progesterone + oestradiol. The increase in observed binding capacity exceeded the increase in 
total protein induced by the hormone(s). These results support the concept that the appearance of RBP in uterine secretions resulted from the specific action of progesterone on secretory activity of the porcine uterine endometrium.

Table 2. Total protein, $\left[{ }^{3} \mathrm{H}\right]$ retinol bound and total vitamin $\mathrm{A}$ recovered from ovariectomized gilts treated with hormones

\begin{tabular}{clccc}
\hline Group & Treatment & $\begin{array}{c}\text { Protein recovered } \\
(\mathrm{mg} / \text { horn })\end{array}$ & $\begin{array}{c}\text { Retinol bound to } \\
\text { Fraction } \mathrm{V}^{*} \\
(\mathrm{pmol} / \text { horn })\end{array}$ & $\begin{array}{c}\text { Total vitamin A } \\
\text { recovered } \\
\text { (nmol/horn) }\end{array}$ \\
\hline 1 & None & $5 \cdot 9 \pm 3 \cdot 0$ & $3 \cdot 1 \pm 3 \cdot 1^{\mathrm{a}}$ & $\mathrm{ND} \dagger$ \\
2 & Oestradiol & $36 \cdot 2 \pm 18 \cdot 5$ & $11 \cdot 0 \pm 11 \cdot 0^{\mathrm{a}}$ & $\mathrm{ND}+$ \\
3 & Progesterone & $85 \cdot 2 \pm 31 \cdot 3$ & $337 \cdot 7 \pm 87 \cdot 0^{\mathrm{b}}$ & $14 \cdot 3 \pm 4 \cdot 8$ \\
4 & $\begin{array}{c}\text { Oestradiol }+ \\
\text { progesterone }\end{array}$ & $98 \cdot 2 \pm 31 \cdot 3$ & $353 \cdot 0 \pm 44 \cdot 1^{\mathrm{b}}$ & $18 \cdot 9 \pm 7 \cdot 9$ \\
\hline
\end{tabular}

\footnotetext{
Values are mean \pm s.e.m. for 3 animals. Means with different superscript letters in the same column are significantly different $(P<0.01)$.

* The binding assay was carried out in duplicate at a retinol concentration of $19 \mathrm{pmol} / \mathrm{ml}$ which is well below the concentration required for saturating the retinol binding protein.

$\dagger$ ND, not detectable by the procedure of Selvanaj \& Susheela (1970).
}

\section{$R B P$ in allantoic fluid and maternal serum}

Allantoic fluid (Day 60 of gestation) was assayed for RBP. Following Biogel P-100 chromatography, the major peak of protein-bound radioactivity appeared close to the elution position of myoglobin and was consistent with the presence of an RBP of molecular weight approximately 17000 .

Serum samples from a pregnant (Day 45) and a non-pregnant (Day 3 of oestrous cycle) pig were assayed for RBP. For both serum types two peaks of binding protein were detected. The first was associated with a protein peak eluting close to the void volume of the calibrated Sephadex G-75 column, while the second appeared in later fractions at a position consistent with a serum RBP having a molecular weight of about 17000 .

\section{Vitamin A in uterine flushings and allantoic fluid}

The vitamin A content of the uterine flushing from gilts in Groups 1-4 is summarized in Table 2. Under the conditions of the assay, significant amounts of vitamin A were detected only in Groups 3 and 4.

The amounts of vitamin $A$ in allantoic fluid samples $(1 \mathrm{ml})$ from Days 30, 45, 60, 75 and 90 of gestation were below the sensitivity limit of the assay.

\section{Discussion}

The epitheliochorial type of placenta of the pig makes it necessary for nutrients to be transferred across an intact uterine epithelium for use by the fetus throughout gestation. The discovery of uteroferrin and now a RBP in flushings from progesterone-treated pigs is consistent with the hypothesis that uterine secretions have a major role in fetal nutrition. We have previously suggested that the endometrial secretions comprise a sophisticated embryo culture medium, containing a number of components which are not apparently present in serum (Bazer et al., 1978; Roberts \& Bazer, 1980).

The RBP described here is apparently secreted under the influence of progesterone and is found in Fraction V during molecular sieve chromatography. It also can be recovered during the 
luteal phase (Day 15) of the oestrous cycle when progesterone levels are high and oestrogens low. Progesterone regulation probably ensures that, like uteroferrin, the RBP will be produced throughout most of pregnancy. The recovery of a similar protein in allantoic fluid is also consistent with the model we have earlier proposed for uteroferrin transport (Chen et al., 1975), i.e. that after secretion by the endometrial surface and glandular epithelium the proteins are taken up at special regions of the chorion known as areolae, and at least part of the material transported to the allantoic fluid, which acts as a storage reservoir for proteins derived from the dam.

The fact that total vitamin A content of secretions was significantly increased in progesterone-treated pigs but not in controls also suggests that nutrient transport across the uterine epithelium is increased during progesterone administration. Its low concentration in allantoic fluid suggests that the vitamin may be stored or rapidly utilized by the conceptus rather than sequestered in fetal fluids.

Uterine RBP appears to differ from cellular and serum RBPs in its affinity for retinol. The cellular proteins have an average $K_{\mathrm{d}}$ of about $1.6 \times 10^{-8} \mathrm{M}$ (Ong \& Chytil, 1978) while the serum species of pig has a $K_{\mathrm{d}}$ of $1.78 \times 10^{-7} \mathrm{M}$ (Muhilal \& Glover, 1975). In binding specificity, secretory RBP resembles the serum species more than the cellular species. Serum RBP, for example, binds retinoic acid almost as well as retinol (Goodman, 1974) and, from this study, it appears that retinoic acid competes with retinol for binding to the secretory protein. By contrast, cellular RBPs do not bind retinoic acid with high affinity (Ong \& Chytil, 1975). None of the RBPs appears to have an affinity for retinyl esters or retinal. The competitive binding of oleic acid, reported here, was unexpected but suggests that the hydrocarbon tail of retinol might be involved in a hydrophobic association with its carrier protein.

Secretory RBP is also similar in molecular weight to serum RBP. Indeed, although these experiments do suggest some differences between the two in affinity for retinol, it has not been possible to prove that the former is synthesized locally within the uterus. It is possible that a selective movement of serum proteins to the uterine lumen occurs under the influence of progesterone. However, the synthesis of several unique proteins, including Fraction $\mathrm{V}$ proteins, is induced locally by progesterone administration (Roberts \& Bazer, 1980).

Ion-exchange chromatography has demonstrated that the specific RBP comprises only a small proportion of Fraction $\mathrm{V}$ protein. The presence of two peaks of binding activity after DEAE-cellulose chromatography may be due to the presence of a retinoic acid-binding protein (K. L. Adams, F. W. Bazer \& R. M. Roberts, unpublished data) which has some affinity for retinol. In addition, the Scatchard analysis showed that only about $6 \times 10^{-2}$ mol retinol were bound per mol protein. Assuming that only 1 molecule of retinol is bound by a single protein molecule, only about $6 \%$ of Fraction $\mathrm{V}$ consisted of RBP. Preliminary results have suggested that a retinoic acid-binding protein with a $K_{\mathrm{d}}$ of $1.3 \times 10^{-6} \mathrm{M}$ is also present (K. L. Adams, F. W. Bazer \& R. M. Roberts, unpublished data) and it is distinct from the RBP reported here. What the function of the other progesterone-induced proteins in this fraction might be is still unclear.

We thank $\mathrm{Mr} \mathrm{W}$. Clark for surgical assistance. The work was supported by grants HD 08560 and HD 10436 from the National Institutes of Health and U.S.D.A. Cooperative Agreement 12-14-7001-1119. Florida Agricultural Experiment Station, Journal Series No. 2395.

\section{References}

Bazer, F.W., Chen, T.T., Knight, J.W., Schlosnagle, D., Baldwin, N.J. \& Roberts, R.M. (1975) Presence of a progesterone-induced, uterine specific, acid phosphatase in allantoic fluid of gilts. J. Anim. Sci. 41, 1376-1382.
Bazer, F.W., Sharp, D.C. \& Roberts, R.M. (1978) Collection and analysis of female genital tract secretions. In Methods in Mammalian Embryology, pp. 503-528. Ed. J. C. Daniel. Academic Press, New York. 
Buhi, W., Bazer, F.W., Ducsay, C., Chun, P.W. \& Roberts, R.M. (1979) Iron content, molecular weight and possible function of the progesterone-induced purple glycoprotein. Fedn Proc. Fedn Am. Socs exp. Biol. 38, 733.

Chen, T.T., Bazer, F.W., Gebhart, B.M. \& Roberts, R.M. (1975) Uterine secretion in mammals: synthesis and placental transport of a purple acid phosphatase in pigs. Biol. Reprod. 13, 304-313.

Chytil, F., Page, D.L. \& Ong, D.E. (1975) Presence of cellular retinol and retinoic acid binding proteins in human uterus. Int. J. Vit. Res. 45, 293-298.

Goodman, D.S. (1974) Vitamin A transport and retinolbinding protein metabolism. Vitams Horm. 32, $167-180$.

Knight, J.W., Bazer, F.W. \& Wallace, H.D. (1973) Hormonal regulation of porcine uterine secretions. $J$. Anim. Sci. 36, 546-553.

Lowry, O.H., Rosebrough, N.J., Farr, A.L. \& Randall, A.J. (1951) Protein measurement using the Folin phenol reagent. J. biol. Chem. 193, 265-275.

Muhilal, H. \& Glover, J. (1975) The affinity of retinol and its analogues for retinol-binding protein. Biochem. Soc. Trans. 3, 744-746.

Murray, F.A., Bazer, F.W., Wallace, H. \& Warnick, A.C. (1972) Quantitative and qualitative variation in the secretion of protein by the porcine uterus during the estrous cycle. Biol. Reprod. 7, 314-320.

Ong, D.E. \& Chytil, F. (1975) Specificity of cellular retinol-binding protein for compounds with vitamin A activity. Nature, Lond. 255, 74-75.

Ong, D.E. \& Chytil, F. (1978) Cellular retinol binding protein from rat liver: purification and characterization. J. biol. Chem. 253, 828-832.

Roberts, R.M. \& Bazer, F.W. (1980) The properties, function and control of synthesis of uteroferrin, the purple protein of the pig uterus. In Steroid Induced Proteins, pp. 133-149. Ed. M. Beato. Elsevier-North Holland, Amsterdam.

Scatchard, G. (1949) The attraction of proteins for small molecules and ions. Ann. N.Y. Acad. Sci. 51, 660-672.

Schlosnagle, D.C., Bazer, F.W., Tsibris, J.C.M. \& Roberts, R.M. (1976) An iron-containing phosphatase induced by progesterone in the uterine fluids of pigs. J. biol. Chem. 249, 7574-7579.

Selvanaja, R.J. \& Susheela, T.P. (1970) Estimation of serum vitamin A by a microfluorometric procedure. Clin. Chim. Acta. 27, 165-170.

Steel, R.G.D. \& Torrie, J.H. (1960) Principles and Procedures of Statistics. McGraw-Hill Book Co., Inc., New York.

Steven, D.H. (1975) Anatomy of the placental barrier. In Comparative Placentation, pp. 25-57. Ed. D. H. Steven. Academic Press, London.

Thompson, J.N., Howell, J.M. \& Pitt, G.A.J. (1964) Vitamin $\mathbf{A}$ and reproduction in rats. Proc. $R$. Soc. B 195, 510-535.

Received 10 June 1980 